\title{
Heat Stability of Pepper Leaf Extracts
}

\author{
Jeffrey A. Anderson 1 \\ Department of Horticulture and Landscape Architecture, Oklahoma State University, 360 Agriculture \\ Hall, Stillwater, OK 74078-6027
}

AdDitional INDEX wORDs. Capsicum annuum, heat stress, protein stability, thermotolerance

\begin{abstract}
Aвstract. Acute high-temperature stress affects plant protein structure, leading to denaturation and aggregation. Although folding states of individual proteins have been extensively studied, little information is available on protein thermostability in complex mixtures. The objective of this study was to systematically examine protein stabilizing and destabilizing factors in pepper (Capsicum annuum $\mathrm{L}$.) leaf extracts using light transmission measurements. Increasing turbidity and subsequent precipitation were monitored in heated extracts as changes in light scattering at $540 \mathrm{~nm}$. Factors evaluated included leaf tissue concentration, buffer $\mathrm{pH}$, compounds that can stabilize enzymatic activity (chelating agent, complexer of phenolics, and a compatible solute), and destabilizing agents (nonionic detergent and divalent cation). Leaf extract thermostability decreased with increasing tissue concentration from 6 to $60 \mathrm{~g}$ fresh weight per liter of buffer. Turbidity and precipitation occurred after exposure to higher temperatures as buffer $\mathrm{pH}$ increased from 6.0 to 7.0. Ethylenediaminetetraacetic acid (chelating agent) and polyvinylpolypyrrolidone (complexer of alkaloids and phenolics) had relatively small effects on extract thermostability. Nonionic detergent (Tween 20) destabilized extract thermostability, especially when incorporated in the extraction buffer. Calcium reduced thermostability by about $2^{\circ} \mathrm{C}$ when added as $\mathrm{CaCl}_{2}$ at $1 \mathrm{~mm}$. Calcium caused an increase in turbidity that was not directly associated with protein complexes and was not affected by treatment temperature. Mannitol, a compatible solute, increased the temperature at which turbidity and precipitation were induced, but only at high $(500 \mathrm{~mm})$ concentrations. Agents that stabilize or destabilize proteins at high temperatures can be assayed in plant extracts by measuring turbidity changes at $540 \mathrm{~nm}$. These findings can be applied to functional studies determining the basis for differences in thermotolerance between genotypes and between control and acclimated tissues.
\end{abstract}

Acute exposure to temperature extremes injures susceptible plant cells by altering membrane structure and function (Nanaiah and Anderson, 1992), through destructive reactions of activated oxygen (Foyer et al., 1997), and from changes in enzyme conformation and activity (Salvucci et al., 2001). Proteins can lose tertiary and quaternary structure at high temperatures. Although the complexity of the process depends on the protein and environment, studies with ovalbumin indicated a reversible, bimolecular transition from the native to unfolded state, followed by irreversible reactions forming denatured and aggregated proteins (Weijers et al., 2003). Partially unfolded proteins have exposed hydrophobic residues that can participate in intra- and inter-molecular bonds, leading to misfolding or aggregation. Molecular chaperones, including heat shock proteins, can bind to exposed hydrophobic regions, thereby reducing the probability of incorrect folding and aggregation (Buchanan et al., 2000).

Researchers have elucidated details of structural changes in individual proteins exposed to elevated temperatures or chaotropic agents using activity assays or changes in physical properties such as circular dichroism. Less information is available about thermal stability of complex solutions such as plant tissues, even though such information would be valuable in elucidating and predicting plant stress responses in the natural environment. Studies with single proteins are not designed to provide information on the interaction of molecules expected to occur in a complex

Received for publication 16 July 2005. Accepted for publication 8 Sept. 2005. Approved for publication by the Director, Oklahoma Agricultural Experiment Station. Research supported by the Oklahoma Agricultural Experiment Station. Mention of a trademark, proprietary product, or vendor does not constitute a guarantee or warranty of the product and does not imply its approval to the exclusion of other products or vendors that also may be suitable. Technical assistance by Ryan Anderson and use of the Controlled Environment Research Laboratory are gratefully acknowledged.

'To whom reprint requests should be addressed. E-mail address: jeff. anderson@okstate.edu system. A previous report using light transmission measurements indicated that leaf extracts from vinca (Catharanthus roseus L.), a heat-tolerant plant, were more thermostable than extracts from sweet pea (Lathyrus odoratus L.), a heat-sensitive plant (Anderson and Padhye, 2004). Therefore, the primary objective was to systematically evaluate protein stabilizing and destabilizing factors in complex systems at high temperatures. Determining the factors that interact to dictate protein thermostability would provide an understanding of one of the main causes of differences in thermotolerance between heat susceptible and resistant plants, and provide a basis for targeted increases in stress resistance. Results can also be applied to functional studies of differences in thermotolerance of plant tissues at different developmental stages or acclimation states.

\section{Materials and Methods}

The effects of the physical and chemical environment on turbidity and precipitation were determined in pepper leaf extracts exposed to heat stress. Extract thermostability was examined spectrophotometrically as changes in light scattering at $\mathrm{pH}$ 's of 6.0, 6.5, and 7.0; in the presence or absence of compounds used to stabilize enzymatic activity [ethylenediaminetetraacetic acid (EDTA, chelating agent), polyvinylpolypyrrolidone (PVPP, complexer of alkaloids and phenolics), and mannitol (compatible solute)]; or in the presence or absence of destabilizing agents [Tween 20 (polyoxyethylene sorbitan monolaurate, nonionic detergent) (ICIAmericas, New Castle, Del.) and calcium (divalent cation)]. All reagents were obtained from Sigma-Aldridge Co. (St. Louis), except for EDTA and MES, which were purchased from Fisher Scientific (Fair Lawn, N.J.).

Plant culture. 'Early Calwonder' pepper seeds were planted in 24-cm-diameter pots in an enriched commercial potting mix (BM-1; Saint-Modeste, Que., Canada). Amendments included dolomite $\left(3.6 \mathrm{~g} \cdot \mathrm{L}^{-1}\right)$, triple superphosphate $\left(0.7 \mathrm{~g} \cdot \mathrm{L}^{-1}\right)$, Micromax 
(The Scotts Co., Marysville, Ohio) $\left(0.6 \mathrm{~g} \cdot \mathrm{L}^{-1}\right)$, and $\mathrm{KNO}_{3}(0.6$ $\left.\mathrm{g} \cdot \mathrm{L}^{-1}\right)$. Plants were grown in a controlled environment chamber (model PGW36; Conviron, Winnipeg, Man., Canada) at $24 / 20^{\circ} \mathrm{C}$ day/night cycles, with $45 \%$ to $65 \%$ relative humidity. The chamber was programmed for 14-h photoperiods with a photosynthetic photon flux density at canopy height of about $400 \mu \mathrm{mol} \cdot \mathrm{m}^{-2} \cdot \mathrm{s}^{-1}$. Plants were watered with $20 \mathrm{~N}-8.6 \mathrm{P}-16.6 \mathrm{~K}$ soluble fertilizer (Peters; The Scotts Co.) at $0.7 \mathrm{~g} \cdot \mathrm{L}^{-1}$ as required, based on lighter growing substrate color and reduced pot weight relative to plants not requiring irrigation.

Plant extracts and heat treatments. Fully-expanded, nonsenescent leaves were excised from 10-week-old plants and rinsed in deionized water, then gently blotted free of surface moisture. The midribs were removed with a razor blade and the leaves were cut into sections. For each treatment, $15 \mathrm{~g}$ fresh weight (FW) of leaf tissue were placed in $240 \mathrm{~mL}$ MES buffer (2-( $N$-morpholino)ethanesulfonic acid (50 mM, pH 6.0) unless specified otherwise. Tissues were homogenized in a blender (Dynamics Corp., New Hartford, Conn.) three times for 10 s each at full speed with $15 \mathrm{~s}$ between blendings. Homogenates were filtered through Miracloth (Calbiochem-Novabiochem Corp., San Diego, Calif.), then centrifuged at $16,000 g_{\mathrm{n}}$ for $20 \mathrm{~min}$ at 24 ${ }^{\circ} \mathrm{C}$. Supernatants were transferred to test tubes $(3.5 \mathrm{~mL}$ in each tube) with three tubes (subsamples) per exposure temperature by treatment combination. Tubes were held in circulating baths at the appropriate test temperatures for $15 \mathrm{~min}$, then placed in a water bath at $24{ }^{\circ} \mathrm{C}$.

TuRbidity AND PRECIPITATION. Visual observations of precipitate formation were recorded $5 \mathrm{~h}$ after temperature treatments, then $1 \mathrm{~mL}$ of the extract was pipetted to a semi-microcuvette for apparent absorbance measurements using a spectrophotometer (model DU640B; Beckman Coulter, Fullerton, Calif.). Light transmission responses were termed apparent absorbance due to light scattering as extracts became turbid. Only the solution above precipitates was sampled in tubes containing extract that formed a precipitate.

Wavelength scans of untreated pepper leaf extracts indicated absorbance maxima at 436 and $679 \mathrm{~nm}$, corresponding to chlorophyll absorption peaks (Buchanan et al., 2000). Apparent absorbance at $540 \mathrm{~nm}$ was also measured based on previous studies of turbidity development in heated egg whites (Watanabe et al., 1999). Absorbance of extracts not exposed to high temperatures was measured at 436, 540, and $679 \mathrm{~nm}$ using buffer as a blank to compare initial conditions across treatments. Turbidity as a function of treatment temperature was monitored at $540 \mathrm{~nm}$ using control samples from each treatment filtered through a $0.2-\mu \mathrm{m}$ polyethersulfone membrane (Nalgene, Rochester, N.Y.) as the blanks.

Tissue Concentration. Thirty-six grams of leaf tissue were homogenized in $600 \mathrm{~mL}$ MES buffer $(50 \mathrm{~mm}, \mathrm{pH}$ 6.0) containing $3.09 \mathrm{~g}$ PVPP that had been pre-moistened with buffer for $\approx 18$ h. The homogenate was filtered through Miracloth, then divided into three aliquots, one was undiluted ( $60 \mathrm{~g} \mathrm{FW}$ tissue per liter of buffer), and the other aliquots were diluted with buffer to 33 or $6 \mathrm{~g} \cdot \mathrm{L}^{-1}$ and mixed before centrifugation. The supernatants were exposed to heat treatments from 40 to $56^{\circ} \mathrm{C}$ for $15 \mathrm{~min}$, or placed directly at $24^{\circ} \mathrm{C}$ (control) and incubated for $5 \mathrm{~h}$ prior to turbidity measurements.

PolyVinylPolyPyrRolidone. Experiments were conducted to determine the effects of PVPP on extract thermostability, with treatments including a control, PVPP added in a split application with one-half during homogenization and one-half in the filtra- tion collection beaker, and PVPP only in the filtration collection beaker. Leaf tissues ( $15 \mathrm{~g}$ ) were 1) homogenized in $225 \mathrm{~mL}$ MES buffer $(50 \mathrm{~mm}, \mathrm{pH} 6.0)$ and filtered into a beaker containing an additional $15 \mathrm{~mL}$ buffer with no PVPP(control), 2) homogenized in $225 \mathrm{~mL}$ buffer with $1.25 \mathrm{~g}$ PVPP, then filtered into a beaker containing an additional $1.25 \mathrm{~g}$ PVPP in $15 \mathrm{~mL}$ buffer, or 3) homogenized in $225 \mathrm{~mL}$ buffer, then filtered through Miracloth into a beaker containing $2.5 \mathrm{~g}$ PVPP in $15 \mathrm{~mL}$ buffer. Filtrates were mixed in the beakers by repeated pipetting and discharging. Polyvinylpolypyrrolidone was allowed to settle for about 2 min, then liquid above the PVPP layer was pipetted into tubes for centrifugation. Supernatants were exposed to $24^{\circ} \mathrm{C}$ (control), or 46 to $52^{\circ} \mathrm{C}$ in $2{ }^{\circ} \mathrm{C}$ increments for $15 \mathrm{~min}$, then incubated at $24{ }^{\circ} \mathrm{C}$ for $5 \mathrm{~h}$ prior to turbidity measurements.

PH. Two sets of experiments were conducted with buffer $\mathrm{pH}$ values ranging from 6.0 to 7.0. In the first experiment, $15 \mathrm{~g}$ of leaf tissue were homogenized in $225 \mathrm{~mL}$ MES buffer solutions that were previously adjusted to $\mathrm{pH} 6.0,6.5$, or 7.0. All three $\mathrm{pH}$ treatments included a split application of PVPP as described above. Supernatants were exposed to $24^{\circ} \mathrm{C}$ (control), or 46 to $62{ }^{\circ} \mathrm{C}$ in $4{ }^{\circ} \mathrm{C}$ increments. In the second experiment, $15 \mathrm{~g}$ of leaf tissue were homogenized in $225 \mathrm{~mL}$ buffer at $\mathrm{pH} 6.0$ with a split PVPP application, then filtered and centrifuged. The supernatant was divided into three aliquots that were adjusted to $\mathrm{pH} 6.0,6.5$, or 7.0. Volumes were adjusted with distilled water to result in the same tissue concentration in each $\mathrm{pH}$ treatment. Supernatants were exposed to $24{ }^{\circ} \mathrm{C}$ (control), $46,50,54,56,58$, or $62{ }^{\circ} \mathrm{C}$ for $15 \mathrm{~min}$ before incubation at $24^{\circ} \mathrm{C}$ for $5 \mathrm{~h}$ and turbidity measurements. The $56^{\circ} \mathrm{C}$ treatment was included to detect the apparent absorbance maximum for the $\mathrm{pH} 7$ treatment.

EDTA. Fifteen $\mathrm{g}$ of leaf tissue were homogenized in $225 \mathrm{~mL}$ MES buffer solutions ( $\mathrm{pH} 6.0$ ) containing 0 , 1, or $5 \mathrm{~mm}$ of the disodium salt of EDTA(Fisher Scientific). All treatments included a split application of PVPP as described above. After filtration and centrifugation, supernatants were exposed to $24^{\circ} \mathrm{C}$ (control), or 46 to $54{ }^{\circ} \mathrm{C}$ in $2{ }^{\circ} \mathrm{C}$ increments before incubation at $24{ }^{\circ} \mathrm{C}$ for $5 \mathrm{~h}$ and turbidity measurements.

Tween 20. Three treatments were imposed to determine the effect of a nonionic surfactant on extract thermostability. The control treatment had $15 \mathrm{~g}$ leaf tissue homogenized in $225 \mathrm{~mL}$ buffer (50 mM MES, pH 6.0, with 1 mM EDTA) with a split PVPP application that included an additional $15 \mathrm{~mL}$ buffer in the filtration vial. The extract was centrifuged, then the supernatant was diluted 1:1 (v/v) with buffer. A second treatment had Tween 20 included in the extraction buffer at $1 \%(\mathrm{w} / \mathrm{v})$. After centrifugation, the supernatant was diluted $1: 1(\mathrm{v} / \mathrm{v})$ with $1 \%(\mathrm{w} / \mathrm{v})$ Tween 20 in MES buffer. The third treatment was the same as the control, except the supernatant was diluted 1:1 (v/v) with $2 \%(\mathrm{w} / \mathrm{v})$ Tween 20 in buffer. A preliminary series of experiments conducted with solutions adjusted to Tween 20 concentrations of $0 \%, 0.01 \%$, or $1.0 \%(\mathrm{w} / \mathrm{v})$ after centrifugation showed a reduction in extract thermostability at $1.0 \%$, but not at $0.01 \%$.

Calcium. Thirty g of leaf tissue were homogenized in 450 mL MES buffer ( $\mathrm{pH}$ 6.0) with a split application of PVPP as described above. After filtration and centrifugation, supernatants were divided into two aliquots. One aliquot was diluted with an equal volume of buffer (control) and the other aliquot was diluted with an equal volume of $2 \mathrm{mM} \mathrm{CaCl}_{2}$ in MES buffer at $\mathrm{pH}$ 6.0. Control and $\mathrm{CaCl}_{2}$ treatments were each divided into two aliquots, and one aliquot was immediately exposed to high-temperature treatments. The remaining portions of the control and $\mathrm{CaCl}_{2}$ treatments were centrifuged a second time, then supernatants 
were exposed to high-temperature treatments. Pellets from the second centrifugation were resuspended to their original volume in MES buffer with the aid of a glass rod and vortex mixer, then exposed to $24^{\circ} \mathrm{C}$ (control), or 44 to $54{ }^{\circ} \mathrm{C}$ in $2{ }^{\circ} \mathrm{C}$ increments before incubation at $24^{\circ} \mathrm{C}$ for $5 \mathrm{~h}$ and turbidity measurements. Protein contents were determined in unheated solutions from each treatment.

Mannitol. Leaf tissue (18.75 g) was homogenized in $300 \mathrm{~mL}$ buffer (50 mм MES, pH 6.0, with 1 mм EDTA) with a split PVPP application. After filtration and centrifugation, the supernatant was diluted 1:1 (v/v) with buffer (control) or mannitol solutions in buffer at 10,100 , or $1000 \mathrm{~mm}$, yielding final mannitol concentrations of $0,5,50$, or $500 \mathrm{~mm}$. The $1000 \mathrm{~mm}$ solution was warmed to $\approx 35$ ${ }^{\circ} \mathrm{C}$ to dissolve all of the mannitol, then cooled to $24{ }^{\circ} \mathrm{C}$ before dilution. Solutions were exposed to temperatures from 42 to 54 ${ }^{\circ} \mathrm{C}$ in $2{ }^{\circ} \mathrm{C}$ increments for $15 \mathrm{~min}$ before incubation at $24{ }^{\circ} \mathrm{C}$ for $5 \mathrm{~h}$ and turbidity measurements. A preliminary experiment was conducted with mannitol included in the homogenization buffer at 0,10 , and $1000 \mathrm{~mm}$.

Protein Content in TURbid ANd PRecipitated EXtracts. A series of experiments was conducted to determine how much protein contributed to turbidity and how much precipitated following high-temperature exposure. Leaf extracts (30 g FW per liter of buffer) were prepared in MES buffer at $\mathrm{pH} 6.0$ containing $1 \mathrm{~mm}$ EDTA with a split PVPP application. Extracts were exposed to 24,48 , or $54{ }^{\circ} \mathrm{C}$ for $15 \mathrm{~min}$. Thirty min after heated samples were placed in a water bath at $24^{\circ} \mathrm{C}$, samples were divided, then one subset was centrifuged a second time. Turbid solutions cleared during the second centrifugation. Only the clear solution over the precipitate was sampled by pipet in the $54{ }^{\circ} \mathrm{C}$ treatment. Protein contents were determined in extracts exposed to 24, 48, and $54{ }^{\circ} \mathrm{C}$, and in supernatants from heated extracts that were centrifuged a second time.

Protein Determinations. Protein contents of unheated solutions were determined by a colorimetric method (Bradford, 1976) using ovalbumen (Sigma) as the standard. Experiments involving Tween 20 included separate standard curves for each Tween concentration due to the contribution of detergents to absorbance at $595 \mathrm{~nm}$ (Hammond and Kruger, 1988).

Data ANAlysis. All experiments were repeated independently on at least three dates and all analyses and assays were conducted in triplicate. Analysis of variance was conducted using PROC GLM (SAS Institute, Cary, N.C.). When a significant treatment $\times$ exposure temperature interaction was observed, mean separation was conducted within exposure temperature by Duncan's multiple range test at $P \leq 0.05$ using treatment $\times$ date as the error term.

\section{Results}

Tissue CONCENTRATION. Thermal stability of extracts decreased with increasing tissue concentration. Apparent absorbance maxima occurred following exposure to $52-54{ }^{\circ} \mathrm{C}$ at $6 \mathrm{~g} \cdot \mathrm{L}^{-1}$, at $49{ }^{\circ} \mathrm{C}$ at $33 \mathrm{~g} \cdot \mathrm{L}^{-1}$, and at $47^{\circ} \mathrm{C}$ at $60 \mathrm{~g} \cdot \mathrm{L}^{-1}$ (Fig. 1). Precipitates were first observed at 56,50 , and $48^{\circ} \mathrm{C}$ for 6,33 , and $60 \mathrm{~g} \mathrm{FW}$ of leaf tissue per liter of buffer, respectively. A concentration of $6 \mathrm{~g} \mathrm{FW}$ of leaf tissue per liter of buffer was near the threshold for detection of apparent absorbance changes, with maximum values less than 0.1 apparent absorbance units (Fig. 1). Extracts containing $60 \mathrm{~g} \cdot \mathrm{L}^{-1}$ exhibited more variability in apparent absorbance readings (higher coefficients of variation) than more dilute extracts at temperatures above the maximum absorbance.

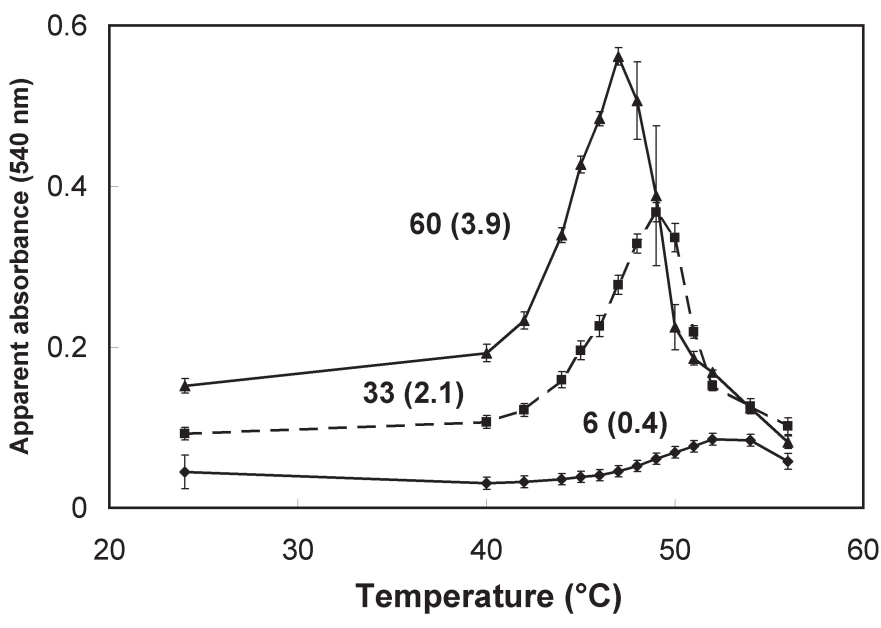

Fig. 1. Apparent absorbance at $540 \mathrm{~nm}$ for pepper leaf extracts containing 6, 33, or $60 \mathrm{~g} \mathrm{FW}$ per liter of buffer after exposure to $24{ }^{\circ} \mathrm{C}$ (control), or 40 to $56^{\circ} \mathrm{C}$ for $15 \mathrm{~min}$. Numbers in parentheses indicate protein concentrations $\left(\mathrm{mg} \cdot \mathrm{mL}^{-1}\right.$ buffer) before heating. Error bars represent \pm SE.

PVPP. While the effect of PVPP at $0.17 \mathrm{~g} \cdot \mathrm{g}^{-1} \mathrm{FW}$ on leaf extract stability was small, a significant treatment by exposure temperature interaction was observed. Apparent absorbance following exposure to $46^{\circ} \mathrm{C}$ was greatest in controls (0.47) and least in extracts prepared with a split application of PVPP $(0.35)$. Treatment differences were not significant after 48 and $50{ }^{\circ} \mathrm{C}$ treatments (data not presented). Preliminary experiments that also included a three-fold greater PVPP concentration (0.5 g PVPP per gram FW of leaf tissue) showed no significant differences in thermotolerance between the two rates (data not presented).

PH. Pepper leaf extracts were more resistant to high-temperature-induced changes in apparent absorbance as the $\mathrm{pH}$ of the extraction buffer increased from 6.0 to 7.0 (Fig. 2). Absorbance maxima occurred following exposure to 46,50 , and $54{ }^{\circ} \mathrm{C}$ for pH 6.0, 6.5, and 7.0, respectively. More refined estimates would have been possible if smaller temperature increments had been used. It is also possible that an absorbance maximum for the $\mathrm{pH}$ 6.0 treatment could have been observed at a lower temperature than $46^{\circ} \mathrm{C}$ if a broader temperature range had been used. Extracts exposed to the highest treatment temperatures had absorbance values $<0$, suggesting that cellular components that passed through a $0.22-\mu \mathrm{m}$ filter contributed to apparent absorbance in filtered

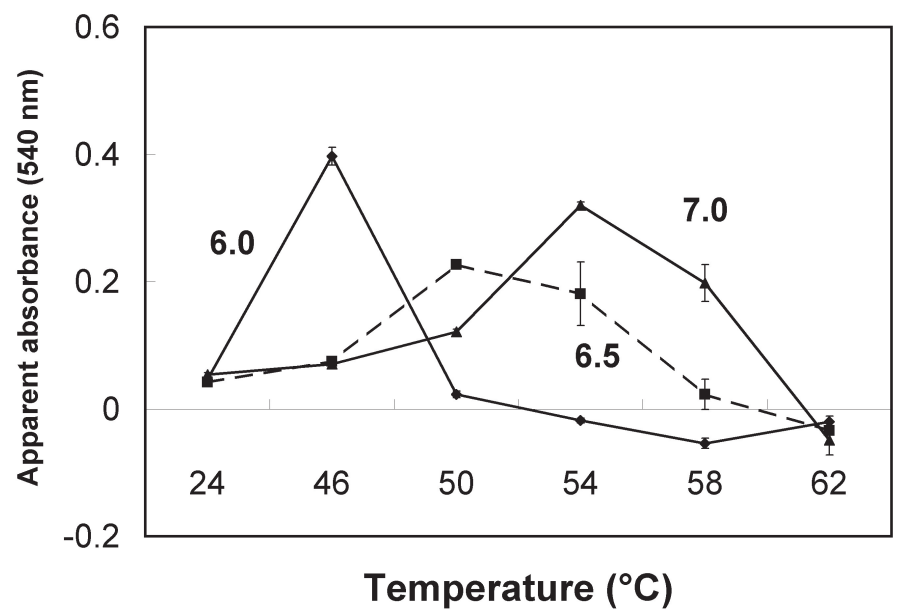

Fig. 2. Apparent absorbance at $540 \mathrm{~nm}$ after exposure to $24^{\circ} \mathrm{C}$ (control), or 46 to $62{ }^{\circ} \mathrm{C}$ in $4{ }^{\circ} \mathrm{C}$ increments for $15 \mathrm{~min}$ for pepper leaf extracts prepared in buffer at $\mathrm{pH} 6.0,6.5$, or 7.0. Error bars represent $\pm \mathrm{SE}$. 
control extracts used as blanks for spectrophotometric measurements, but were removed by thermally-induced aggregation and precipitation.

The increase in thermal stability at higher $\mathrm{pH}$ was not due to $\mathrm{pH}$-related extraction differences because leaf extracts obtained by homogenization at $\mathrm{pH} 6.0$, followed by adjustment of aliquots to $6.0,6.5$, or 7.0 exhibited the same trend as buffer initially adjusted to these pHs. Absorbance maxima were observed following exposure to 46,54 , and $56^{\circ} \mathrm{C}$ for $\mathrm{pH} 6.0,6.5$, and 7.0, respectively (Fig. 3). Extracts blended in $\mathrm{pH} 6.5$ buffer appeared less thermotolerant than extracts adjusted to $\mathrm{pH} 6.5$ after blending. Responses for extracts at $\mathrm{pH} 7.0$ (adjusted before and after homogenization) may be comparable since the $4{ }^{\circ} \mathrm{C}$ temperature intervals (Fig. 2) may have missed a maxima that was observed in experiments that involved a $2{ }^{\circ} \mathrm{C}$ temperature increment (Fig. 3). Subsequent experiments used $\mathrm{pH} 6.0$ extraction buffer to match the $\mathrm{pH}$ of pepper leaf tissue homogenized in distilled water (data not presented).

EDTA. EDTA at a 5 mm concentration significantly increased apparent absorbance following exposure to $46{ }^{\circ} \mathrm{C}$, compared with $1 \mathrm{~mm}$ EDTA and the control extract (Fig. 4). Apparent absorbance at $540 \mathrm{~nm}$ was not significantly affected by EDTA at temperature treatments of 48 and $50{ }^{\circ} \mathrm{C}$. Although leaf extracts tended to precipitate at lower temperatures as EDTA concentration increased from 1 to $5 \mathrm{~mm}$, the trend was not significant (data not presented).

Tween 20. Tween 20 reduced extract thermostability, with a greater effect observed when the surfactant was included in the extraction buffer. Apparent absorbance maxima occurred at 50, 48 , and $46^{\circ} \mathrm{C}$ for control, Tween 20 added after extraction, and Tween 20 included in the extraction buffer, respectively (Fig. $5)$. The same trend was observed when comparing temperatures at which precipitation first was observed. Protein contents were similar between the control and the treatment with Tween 20 added after extraction, but were significantly greater when the surfactant was included in the extraction buffer (Table 1). Apparent absorbance of unheated extracts at 436, 540, and $679 \mathrm{~nm}$ were significantly greater when Tween 20 was included in the extraction buffer, compared with the control and treatment with Tween 20 added after extraction (Table 1).

Calcium. Calcium reduced pepper leaf extract thermostability by $\approx 2{ }^{\circ} \mathrm{C}$ based on the apparent absorbance maxima (Fig. 6) for the control and calcium treatments that were centrifuged once. However, there was no significant difference in apparent absorbance between control and calcium treatments that were centrifuged a second time. The lowest temperature resulting in precipitation was not significantly different between control and calcium treatments centrifuged one or two times (Table 2). Resuspended pellets did not form precipitates or exhibit apparent absorbance changes as a function of temperature. Resuspended pellets from the control treatment had very low apparent absorbance values, but the calcium treatment had moderate apparent absorbance values (Fig. 6 ). The large increase in turbidity observed when calcium was added to samples centrifuged once was eliminated by a second centrifugation. Protein contents were not significantly affected by calcium treatment or number of centrifugations (Table 2). Protein contents were significantly lower in resuspended pellets compared with supernatants.

Mannitol. Mannitol had little or no effect on extract thermostability at 5 or $50 \mathrm{~mm}$ (Fig. 7). The apparent absorbance maximum and onset of precipitation occurred at $2{ }^{\circ} \mathrm{C}$ higher temperature in the $500 \mathrm{~mm}$ solution, compared with solutions containing 0,5 , or

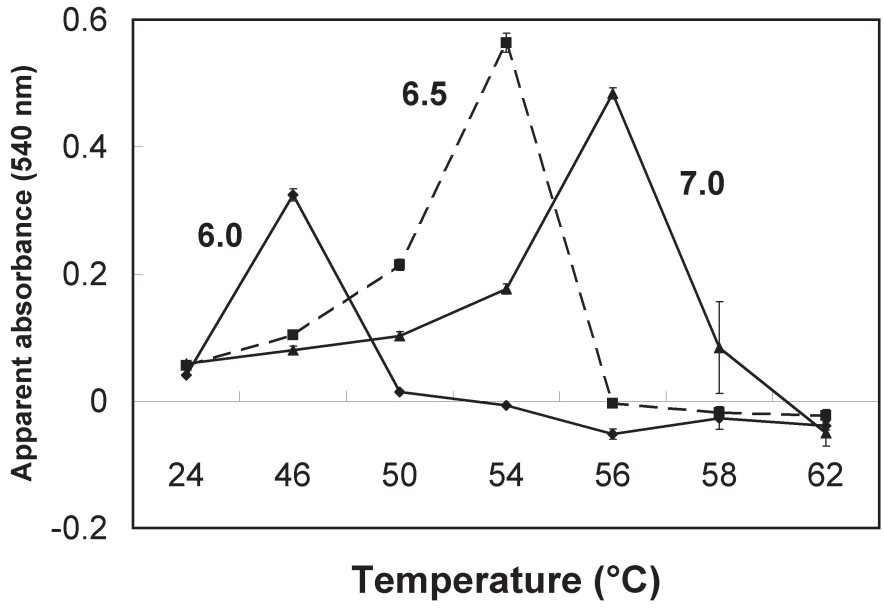

Fig. 3. Apparent absorbance at $540 \mathrm{~nm}$ after exposure to $24^{\circ} \mathrm{C}$ (control), 46,50 , $54,56,58$, or $62^{\circ} \mathrm{C}$ for $15 \mathrm{~min}$ for pepper leaf extracts prepared in buffer at $\mathrm{pH}$ 6.0 , then adjusted to $\mathrm{pH} 6.0,6.5$, or 7.0. Error bars represent \pm SE.

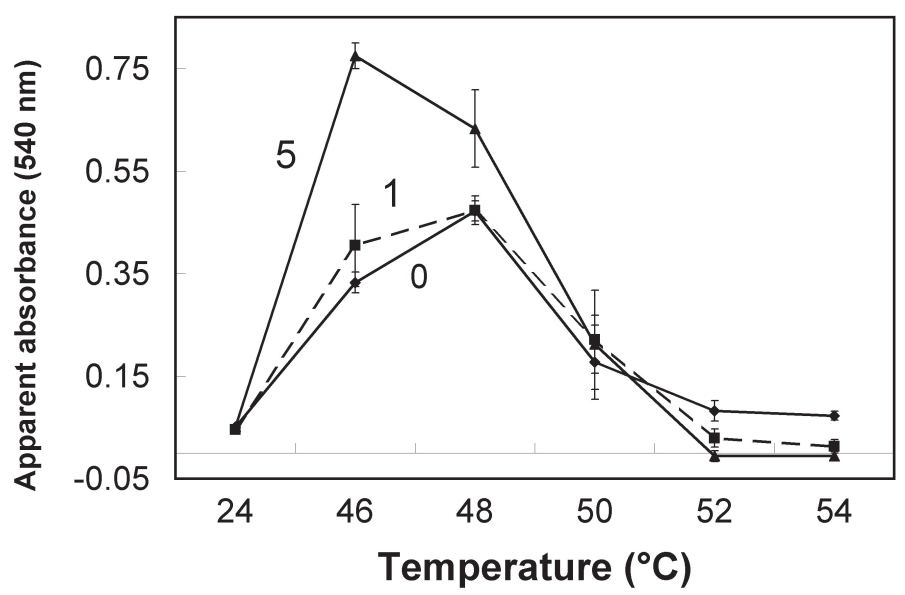

Fig. 4. Apparent absorbance at $540 \mathrm{~nm}$ after exposure to $24{ }^{\circ} \mathrm{C}$ (control), or 46 to $54{ }^{\circ} \mathrm{C}$ in $2{ }^{\circ} \mathrm{C}$ increments for 15 min for pepper leaf extracts prepared in EDTA solutions of 0,1 , or $5 \mathrm{~mm}$. Leaf tissue ( $60 \mathrm{~g} \mathrm{FW}$ per liter of buffer) was homogenized in buffer at $\mathrm{pH}$ 6.0. Error bars represent \pm SE.

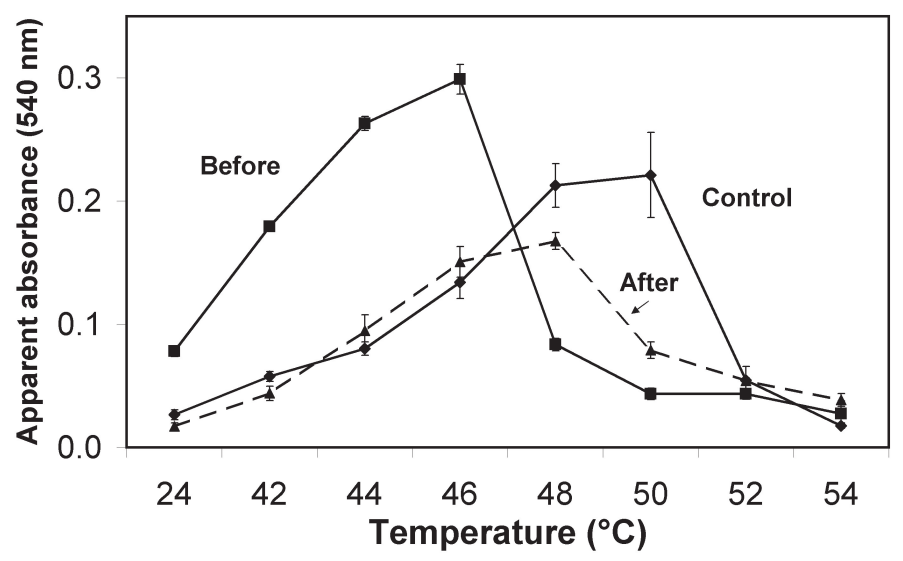

Fig. 5. Apparent absorbance at $540 \mathrm{~nm}$ after exposure to $24^{\circ} \mathrm{C}$ (control), or 42 to $54{ }^{\circ} \mathrm{C}$ in $2{ }^{\circ} \mathrm{C}$ increments for $15 \mathrm{~min}$ for pepper leaf extracts prepared in $\mathrm{pH} 6.0$ buffer (control), homogenized in buffer containing 1\% (M/V) Tween 20 (before), or homogenized in buffer, then made to $1 \%$ Tween 20 (after). Leaf extracts contained $30 \mathrm{~g} \mathrm{FW}$ per liter of buffer after dilution. Error bars represent $\pm \mathrm{SE}$. 
Table 1. Protein content (fresh weight basis) of pepper leaf extracts and apparent absorbance (AA) values at 436, 540, and $679 \mathrm{~nm}$ for control, Tween 20 added after extraction, and Tween 20 added before extraction at $1 \%(\mathrm{w} / \mathrm{v})$.

\begin{tabular}{lcccc}
\hline Treatment & $\begin{array}{c}\text { Protein } \\
\left(\mathrm{mg} \cdot \mathrm{g}^{-1}\right)\end{array}$ & $\mathrm{AA}_{436}$ & $\mathrm{AA}_{540}$ & $\mathrm{AA}_{679}$ \\
\hline Control & $45.2 \mathrm{a}^{\mathrm{z}}$ & $0.42 \mathrm{a}$ & $0.07 \mathrm{a}$ & $0.25 \mathrm{a}$ \\
After & $46.5 \mathrm{a}$ & $0.40 \mathrm{a}$ & $0.05 \mathrm{a}$ & $0.22 \mathrm{a}$ \\
Before & $56.4 \mathrm{~b}$ & $---\mathrm{y}$ & $0.25 \mathrm{~b}$ & $1.81 \mathrm{~b}$ \\
\hline
\end{tabular}

${ }^{\mathrm{z}}$ Mean separation within columns was by Duncan's multiple range test at $P \leq 0.05$.

yApparent absorbance value was $>2.0$ and not considered reliable. A 10 -fold dilution had a mean $\mathrm{AA}_{436}$ value of 0.30 .

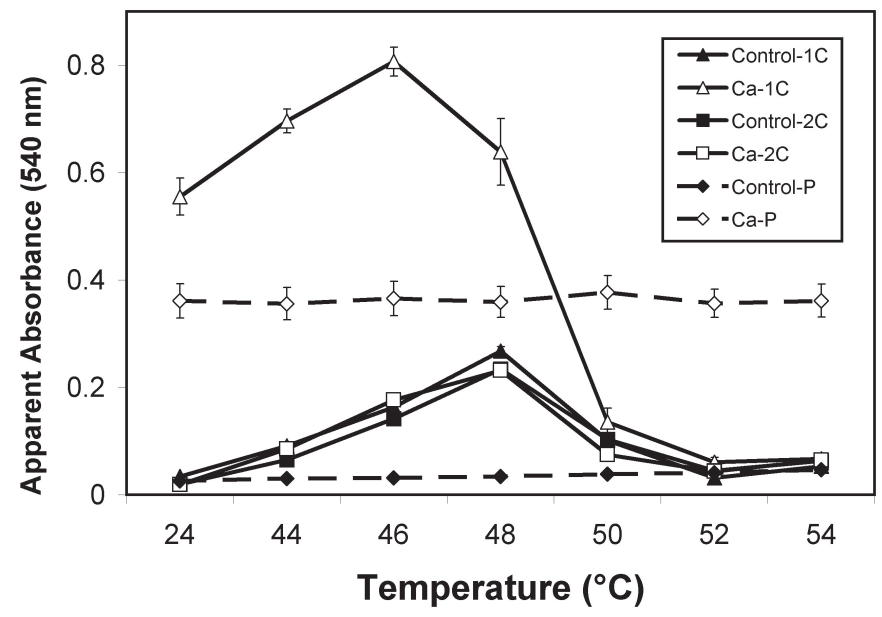

Fig. 6. Apparent absorbance at $540 \mathrm{~nm}$ after exposure to $24^{\circ} \mathrm{C}$ (control), or 44 to $54{ }^{\circ} \mathrm{C}$ in $2{ }^{\circ} \mathrm{C}$ increments for $15 \mathrm{~min}$ for pepper leaf extracts in $\mathrm{pH} 6.0$ buffer (control), or buffer containing $1 \mathrm{~mm} \mathrm{CaCl}(\mathrm{Ca})$. Samples were centrifuged once (1C), twice (2C), or prepared from resuspended pellets after the second centrifugation $(\mathrm{P})$. Leaf extracts contained $30 \mathrm{~g} \mathrm{FW}$ per liter of buffer after dilution. Error bars represent \pm SE.

Table 2. Protein content (fresh weight basis) of pepper leaf extracts, apparent absorbance (AA) values at 436, 540, and $679 \mathrm{~nm}$, and lowest temperature resulting in precipitate formation for control and $1 \mathrm{~mm}$ calcium treatments that were centrifuged once (1C), twice (2C), or centrifuged twice and resuspended from the pellet $(\mathrm{P})$.

\begin{tabular}{lccccc}
\hline Treatment & $\begin{array}{c}\text { Protein } \\
\left(\mathrm{mg} \cdot \mathrm{g}^{-1}\right)\end{array}$ & $\mathrm{AA}_{436}$ & $\mathrm{AA}_{540}$ & $\mathrm{AA}_{679}$ & $\begin{array}{c}\text { Precipitate } \\
\text { temp }(\mathrm{C})\end{array}$ \\
\hline Control-1C & $72.4 \mathrm{a}^{\mathrm{z}}$ & $0.49 \mathrm{c}$ & $0.08 \mathrm{c}$ & $0.29 \mathrm{c}$ & $50.0 \mathrm{a}$ \\
Calcium-1C & $72.1 \mathrm{a}$ & $1.26 \mathrm{a}$ & $0.75 \mathrm{a}$ & $0.81 \mathrm{a}$ & $49.3 \mathrm{a}$ \\
Control-2C & $70.7 \mathrm{a}$ & $0.32 \mathrm{~d}$ & $0.05 \mathrm{c}$ & $0.18 \mathrm{~d}$ & $50.0 \mathrm{a}$ \\
Calcium-2C & $69.5 \mathrm{a}$ & $0.32 \mathrm{~d}$ & $0.05 \mathrm{c}$ & $0.18 \mathrm{~d}$ & $50.0 \mathrm{a}$ \\
Control-P & $0.7 \mathrm{~b}$ & $0.17 \mathrm{e}$ & $0.03 \mathrm{c}$ & $0.11 \mathrm{~d}$ & None \\
Calcium-P & $1.5 \mathrm{~b}$ & $0.71 \mathrm{~b}$ & $0.48 \mathrm{~b}$ & $0.44 \mathrm{~b}$ & None \\
\hline
\end{tabular}

$\overline{\text { zMean separation within columns was by Duncan's multiple range test }}$ at $P \leq 0.05$.

$50 \mathrm{~mm}$ mannitol. In preliminary experiments, mannitol had no effect on extract thermostability when included in the extraction buffer at $10 \mathrm{~mm}$, but $1000 \mathrm{~mm}$ mannitol increased stability by about $4{ }^{\circ} \mathrm{C}$ (data not presented).

Protein Content in tURBID AND PRecipitated eXtracts. Compared with the $24{ }^{\circ} \mathrm{C}$ control, protein contents decreased $11 \%$ in extracts that became turbid after heating to $48^{\circ} \mathrm{C}$, and decreased $75 \%$ in the solution over the precipitate in extracts heated to $54{ }^{\circ} \mathrm{C}$ (Fig. 8). Centrifuging extracts a second time following heat treatments decreased protein contents $2 \%$ to $3 \%$

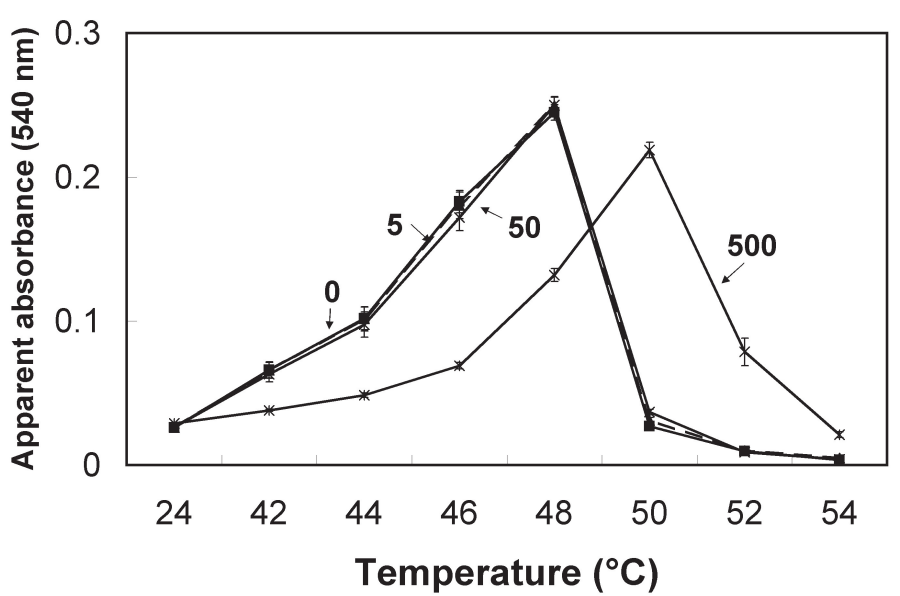

Fig. 7. Apparent absorbance at $540 \mathrm{~nm}$ after exposure to $24{ }^{\circ} \mathrm{C}$ (control), or 42 to $54{ }^{\circ} \mathrm{C}$ in $2{ }^{\circ} \mathrm{C}$ increments for $15 \mathrm{~min}$ for pepper leaf extracts made to 0,5 , 50 , or $500 \mathrm{~mm}$ mannitol after homogenization and centrifugation. Leaf extracts were prepared in buffer ( $\mathrm{pH} 6.0$ ) and contained $30 \mathrm{~g} \mathrm{FW}$ per liter of buffer after dilution. Error bars represent \pm SE.

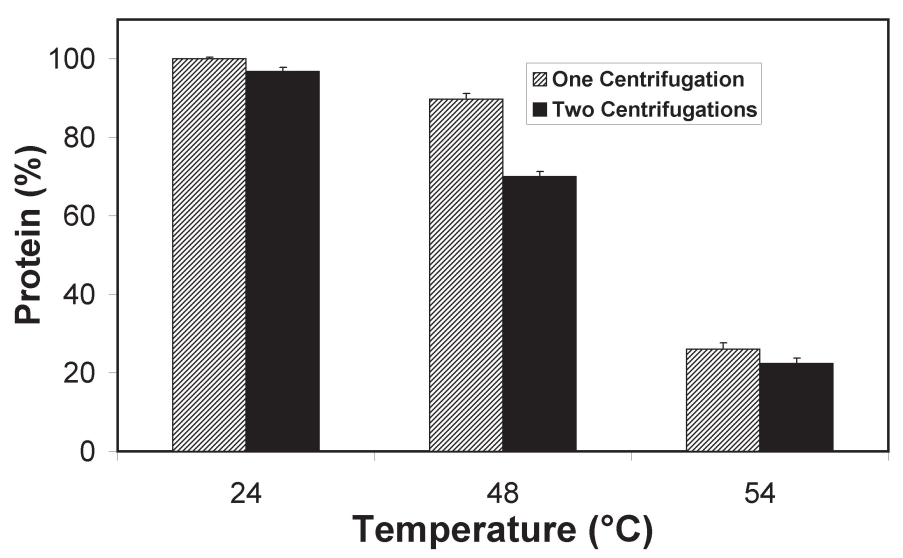

Fig. 8. Protein contents in pepper extracts ( $30 \mathrm{~g} \mathrm{FW}$ per liter of buffer) exposed to 24,48 , or $54^{\circ} \mathrm{C}$ (one centrifugation), or centrifuged a second time after heat treatments (two centrifugations). Values are presented relative to the $24^{\circ} \mathrm{C}$-one centrifugation treatment. Extracts were centrifuged at $16,000 \mathrm{~g}_{\mathrm{n}}$ for $20 \mathrm{~min}$ at $24^{\circ} \mathrm{C}$. Error bars represent $\pm \mathrm{SE}$.

in the 24 and $54{ }^{\circ} \mathrm{C}$ treatments, but protein in the extract exposed to $48^{\circ} \mathrm{C}$ declined by $19 \%$.

\section{Discussion}

Leaf extract thermostability can be monitored through changes in apparent absorbance. However, studies examining the effects of compounds that stabilize or destabilize extracts at high temperatures must control variables such as $\mathrm{pH}$ and tissue concentration. Since the ratio of leaf tissue mass to extraction buffer volume affected thermal stability of the pepper extracts, comparisons should be made across treatments with the same concentration. It is likely that a greater concentration of leaf proteins provided more opportunities for intermolecular interactions leading to turbidity and precipitation following exposure to elevated temperatures. A previous study examining thermal stability of a keratinocyte growth factor indicated that although initial unfolding steps were concentration independent, subsequent aggregation was concentration dependent (Chen et al., 1994). Leaf extract thermostability was strongly affected by $\mathrm{pH}$, even though a small range in $\mathrm{pH}$ was examined. $\mathrm{pH}$-induced changes 
in ionization state of amino acid side groups would be expected to alter protein conformation and potential for electrostatic and hydrophobic interactions.

PVPPandEDTAare commonly included as stabilizers in extraction buffers in studies of enzyme activity of plant tissue extracts. PVPP is reported to complex with alkaloids and phenolics that can bind with proteins. Polyphenolics act as bridges linking together protein molecules, with high temperatures increasing the number of phenol binding sites on proteins (Siebert et al., 1996). Although the effects of PVPP on pepper leaf extract thermostability were small, they were consistent with protein stabilization. EDTA has been routinely employed in protein extractions due to its chelating function. In the present study, EDTA had no significant effect at $1 \mathrm{~mm}$, but increased turbidity at $5 \mathrm{~mm}$. The cause of the increase in turbidity at $5 \mathrm{~mm}$ is not known. It is possible that protein-protein interactions leading to turbidity and aggregation in pepper leaf extracts were primarily hydrophobic and were secondarily affected by the availability of divalent cations at physiological concentrations. In a previous report, EDTA had a moderate effect on protein stabilization, even though it inhibited the formation of disulfide linkages in aggregates (Chen et al., 1994).

Tween 20, a nonionic detergent, destabilized pepper leaf extracts at high temperatures, especially when included in the extraction buffer. Detergents are included in the extraction buffer when a greater proportion of membrane-associated proteins are desired. Consistent with enhanced removal of membrane-associated proteins, buffer containing Tween 20 yielded significantly more protein than buffer without the detergent. Another indication of a less polar solvent was the large increase in apparent absorbance at 436 and $679 \mathrm{~nm}$ (Table 1), consistent with greater extraction of chlorophyll. Membrane-associated proteins contain a greater proportion of hydrophobic residues and may be more susceptible to heat-induced aggregation than soluble proteins.

Calcium destabilized pepper leaf extracts at elevated temperatures. Divalent cations, such as calcium, have the potential to bridge molecules with negative charges. Linking of proteins may have contributed to the observed decrease in thermostability when calcium was added at $1 \mathrm{~mm}$. A secondary result of introducing calcium was to increase the turbidity in the absence of hightemperature treatment. However, the increased turbidity did not appear to involve significant amounts of protein because a second centrifugation eliminated the turbidity without significantly reducing the protein content. Removal of the calcium-induced turbidity by centrifugation restored thermostability to control levels.

Mannitol has been reported to provide multi-functional benefits to plants, based on action as a compatible solute, free radical scavenger, or molecular chaperone (Bohnert and Jensen, 1996). Although osmolytes are often associated with osmotic adjustment to water stress, their action also may be similar to chaperones, stabilizing proteins at high temperatures (Diamant et al., 2001). However, the mannitol concentration range necessary for thermoprotection was greater than found in most plants, with the possible exception of salt-adapted celery (Apium graveolens L.). Vacuole and cytosol levels of mannitol were calculated at 102 and $320 \mathrm{~mm}$ in celery plants exposed to $\mathrm{NaCl}$ (Stoop et al., 1996).

Previous studies have shown that different proteins can vary widely in thermal stability. For example, rubisco activase formed aggregates at $45^{\circ} \mathrm{C}$, but rubisco was stable to $65^{\circ} \mathrm{C}$ (Salvucci et al., 2001). Considerable information on the molecular basis for differences in protein stability has been gained from studies of isozymes from mesophilic and thermophilic bacteria, and from site-directed mutagenesis (Bogin et al., 2002; Sakaue and
Kajiyama, 2003). Model systems have also been very useful in elucidating the steps from native protein to partially folded intermediates, to aggregated complexes. Intermolecular hydrophobic interactions between partially unfolded proteins compete with intramolecular bonding that leads back to the native conformation (Shin et al., 2002). Many heat shock proteins function as molecular chaperones, protecting exposed hydrophobic regions on thermally unfolded proteins and inhibiting aggregation (Jacob et al., 1995). A number of osmolytes, including polyols and amino acids, play a similar role in protein stabilization, acting as chemical chaperones. Similar to results reported here for mannitol, relatively high concentrations were required for protection of creatine kinase (Ou et al., 2002).

Studies of thermal stability of individual proteins has provided useful information on the molecular events taking place. The present study indicates that protein unfolding and aggregation can also be studied in complex systems, allowing interactions between many different molecular species. Further examination of factors affecting thermal stability of plant extracts has implications in understanding changes that take place during acclimation, and factors contributing to a range in thermotolerance in different species, tissues, and stages of development.

Although turbid solutions are not suitable for spectrophotometric assays relying on absorption, changes in plant extract turbidity and precipitation following heat stress could be quantified by light transmission measurements. Thermal stability of pepper leaf extracts was strongly affected by $\mathrm{pH}$ and the presence of a surfactant, factors likely to affect protein conformation. Among the factors evaluated, EDTA and PVPP, additives commonly used during extraction for enzyme assays, had less marked effects on turbidity and precipitation.

\section{Literature Cited}

Anderson, J.A. and S.R. Padhye. 2004. Protein aggregation, radical scavenging capacity, and stability of hydrogen peroxide defense systems in heat-stressed vinca and sweet pea leaves. J. Amer. Soc. Hort. Sci. 129:54-59.

Bogin, O., I. Levin, Y. Hacham, S. Tel-Or, M. Peretz, F. Frolow, and Y. Burstein. 2002. Structural basis for the enhanced thermal stability of alcohol dehydrogenase mutants from the mesophilic bacterium Clostridium beijerinckii: Contribution of salt bridging. Protein Sci. 11:2561-2574.

Bohnert, H.J. and R.G. Jensen. 1996. Strategies for engineering waterstress tolerance in plants. Trends Biotechnol. 14:89-97.

Bradford, M.M. 1976. A rapid and sensitive method for the quantitation of microgram quantities of protein utilizing the principle of protein-dye binding. Anal. Biochem. 72:248-254.

Buchanan, B.B., W. Gruissem, and R.L. Jones. 2000. Biochemistry and molecular biology of plants. Amer Soc. Plant Physiol., Rockville, Md.

Chen, B., T. Arakawa, C.F. Morris, W.C. Kenny, C.M. Wells, and C.G. Pitt. 1994. Aggregation pathway of recombinant human keratinocyte growth factor and its stabilization. Pharm. Res. 11:1581-1587.

Diamant, S., N. Eliahu, D. Rosenthal, and P. Goloubinoff. 2001. Chemical chaperones regulate molecular chaperones in vitro and in cells under combined salt and heat stresses. J. Biol. Chem. 276:39586-39591.

Foyer, C.H., H. Lopez-Delgado, J.H. Dat, and I.M. Scott. 1997. Hydrogen peroxide and glutathione-associated mechanisms of acclimatory stress tolerance and signaling. Physiol. Plant. 100:241-254.

Hammond, J.B.W. and N.J. Kruger. 1988. The Bradford method for protein quantitation, p. 25-32. In: J.M. Walker (ed.). Methods in molecular biology. Humana, Clifton, N.J.

Jacob, U., H. Lilie, I. Meyer, and J. Buchner. 1995. Transient interaction of hsp90 with early unfolding intermediates of citrate synthase. J. Biol. Chem. 270:7288-7294. 
Nanaiah, G.K. and J.A. Anderson. 1992. Electrolyte leakage and evolution of ethylene and ethane from pepper leaf disks following temperature stress and fatty acid infiltration. J. Amer. Soc. Hort. Sci. 117:846-851.

Ou, W.B., Y.D. Park, and H.M. Zhou. 2002. Effect of osmolytes as folding aids on creatine kinase refolding pathway. Intl. J. Biochem. Cell Biol. 34:136-147.

Sakaue, R. and N. Kajiyama. 2003. Thermostabilization of bacterial fructosyl-amino acid oxidase by directed evolution. Appl. Environ. Microbiol. 69:139-145.

Salvucci, M.E., K.W. Osteryoung, S.J. Crafts-Brandner, and E. Vierling. 2001. Exceptional sensitivity of rubisco activase to thermal denaturation in vitro and in vivo. Plant Physiol. 127:1053-1064.

Shin, I., E. Wachtel, E. Roth, C. Bon, I. Silman, and L. Weiner. 2002. Thermal denaturation of Bungarus fasciatus acetylcholinesterase:
Is aggregation a driving force in protein unfolding? Protein Sci. 11:2022-2032.

Siebert, K.J., N.V. Trooukhanova, and P.Y. Lynn. 1996. Nature of polyphenol-protein interactions. J. Agr. Food Chem. 44:80-85.

Stoop, J.M.H., J.D. Williamson, and D.M. Pharr. 1996. Mannitol metabolism in plants: A method for coping with stress. Trends Plant Sci. 5:139-144.

Watanabe, K., J.Q. Xu, and M. Shimoyamada. 1999. Inhibiting effects of egg white dry-heated at $120^{\circ} \mathrm{C}$ on heat aggregation and coagulation of egg white and characteristics of dry-heated egg white. J. Agr. Food Chem. 47:4083-4088.

Weijers, M., P.A. Barneveld, M.A. Cohen-Stuart, and R.W. Visschers. 2003. Heat-induced denaturation and aggregation of ovalbumin at neutral $\mathrm{pH}$ described by irreversible first-order kinetics. Protein Sci. 12:26-93-2703. 